\title{
FAMILY, MEMORY AND DEATH IN THE TOMB INSCRIPTIONS OF MEDIOLANUM (I-II AD)
}

Luciane Munhoz de Omena ${ }^{1}$

Margarida Maria de Carvalho²

\begin{abstract}
Considering contemporary studies on attitudes towards death and the dead, we will consider, given the documentary, thematic and historical relevance, some epitaphs for females present in the region of Mediolanum, the modern city of Milan. We know that, although we do not have remains of necropolises, as in Isola Sacra, the mortuary evidences present at Civico Museo Archeologico di Milano exhibit a wide range of stone stelae, lastras of funeral monuments with stone garlands, marble funeral altars and urns, highlighting the richness of a region known, at the time of $49 \mathrm{BC}$, as municipium ciuium romanorum. In this respect, it becomes relevant to analyze, for example, a gorgeous stela, dated between the last years of the second century $\mathrm{AD}$, as a rare testimony of a woman who, undoubtedly, with a strong personality, commissions the funeral monument to her relatives. Thenceforth, we understand that the epitaphs immortalized the deceased as well as stimulated the pietas of their relatives. Thus, in referring to the sepulchral epigraphy, we emphasize the connections and symbology between written and spoken words, for, thus conceived, ritual repetition evoked the memory of the deceased.
\end{abstract}

\section{Keywords}

Family; death; memory; tomb inscriptions.

\footnotetext{
1 Assistant Professor, Federal University of Goiás, Goiânia, Brazil. E-mail:

lucianemunhoz34@gmail.com

2 Assistant Professor, São Paulo State University, Franca, Brazil. E-mail: margomc@terra.com.br
} 


\section{Resumo}

Ao levar em consideração os estudos contemporâneos sobre as atitudes diante da morte e dos mortos, analisaremos, dada à relevância documental, temática e histórica, alguns epitáfios femininos presentes na região de Mediolanum, atual cidade de Milão. Sabemos que, embora não tenhamos vestígios de necrópoles, tal como em Isola Sacra, os testemunhos mortuários presentes no Civico Museo Archeologico di Milano apresentam uma vasta gama de estelas em pedras, lastras de monumentos funerários com guirlandas em pedra, altares e urnas funerárias em mármores, evidenciando a riqueza de uma região conhecida, à época de 49 a.C., como municipium ciuium romanorum. Sob esse aspecto, torna-se relevante analisar, por exemplo, uma elegante estela, datada entre os anos finais do século II $\mathrm{d}$. C., como um raro testemunho de uma mulher que, sem dúvida, com uma forte personalidade, comissiona o monumento funerário aos seus familiares. A partir daí, compreendemos que os epitáfios imortalizavam os falecidos bem como estimulavam a pietas de seus familiares. Logo, ao fazer referência à epigrafia sepulcral, realçamos as conexões e as simbologias entre palavras escritas e faladas, pois, assim concebida, a repetição ritual evocava a memória do falecido.

\section{Palavras-chave}

Família; morte; memória; inscrições sepulcrais. 
When we think about archaeological and mortuary studies, their symbologies, military research and history theory in Roman society, it sends us to our illustrious Prof. Dr. Pedro Paulo Abreu Funari, to whom we express our sincere thanks for having assisted us in our academic formation. Under his supervision, in the years 2006 (Margarida Maria de Carvalho) and 2015 (Luciane Munhoz de Omena), we carried out our first post-doctoral stages, with funding from CNPq/PDJ and CAPES/FAPEG, respectively, at the Instituto de Filosofia e Ciências Humanas of UNICAMP. This partnership made possible the publication of several articles in co-authorship and the production of collections with the referred professor, such as, for example, Military History of the Ancient World (2012), Funeral Practices in the Roman Mediterranean (2016), Epistemological Diversities (2017), Social Experiences of Death: Interdisciplinary Dialogues (2017), Religions and Religiosity in Late Antiquity (2017), among other productions. ${ }^{3}$ It is noted, therefore, that the postdoctoral stages gathered researchers linked to Brazilian and international public institutions, which, aligned with our research on material culture, memory, death, Roman army and theory of history in antiquity, provided time and work, pledged us with articles.

In this fruitful scenario, we propose to reflect on the family relations represented in the sepulchral epigraphy, to investigate the social experience of death in the family environment of the Mediterranean society of Mediolanum. We consider that material culture is inseparable from social life. The objects are sized, classified and employed in societies, since, as Eckardt and Williams suppose (2003: 141, see also Guarinello, 2011), just like people, objects have a social history. Then, under the condition of an object, writing printed in inscription, commonly known as epigraphe, could have surfaces, such as wax blocks, copper, household items, fragments of ceramics, bones, stones, among others (Cooley, 2012). Here, without reservation, the epitaphs, components of building and funerary monuments, which composed the Roman road scenario, transfigured into an observatory for passers-by, thus becoming symbols

${ }^{3}$ CARVAlHO, M. M.; FUNARI, P. P. A.; CARLAN, C. U.; SILVA, E. C. M. (Orgs.). História Militar no Mundo Antigo. São Paulo: Annablume, Fapesp, Unicamp, 2012, 3 volumes. OMENA, L.; FUNARI, P. P. A. (Orgs.). Práticas Funerárias no Mediterrâneo Romano. 1. ed. Jundiaí, SP: Paco, 2016. FUNARI, P. P. A.; CARVALHO, M. M.; JOSÉ, N. F. (Orgs.). Diversidade Epistemológicas: A teoria aplicada à pesquisa histórica. 01. ed. Curitiba: Prismas, 2017. OMENA, L. M.; FUNARI, P. P. A. (Orgs.). Experiências sociais da morte: diálogos interdisciplinares. 1. ed. Jundiaí, SP: Paco Editoria, 2017. CARVALHO, M. M.; FUNARI, P. P. A.; CARLAN, C. U.; PAPA, Helena Amália (Orgs.). Religiões e Religiosidades na Antiguidade Tardia. 1. ed. Curitiba: Editora Prismas, 2017. 
of wealth and social prestige for the deceased relatives (Cf. WallaceHadrill, 2008: 43).

It can be observed that epigraphic records, as proposed by Ray Laurence (2012: 06), are integrated into society. The life of an individual can be recounted in a narrative that designates, in many circumstances, a past event associated with his family relationships, with the exploration of the course of a life, and with the construction of future projections. ${ }^{4}$ It is therefore relevant to analyze, in this sense, a charming stela, dated between the last years of the second century $\mathrm{AD}$, as a rare testimony of a woman, Segunda Bolana, who, undoubtedly, with a strong personality, commissions the funeral monument to her relatives.

We believe that tomb inscriptions have become indispensable. We even get to know when it comes to a funerary relief by the epitaph. Even in the absence of funerary buildings, inscriptions often provide us with information about the measures of the grave, such as information on the grave of Segunda Bolana, indicating its measures. In this case, the testimony presents the following information: "15 feet on the facade and 30 feet deep" [In fr(onte) p(edes) XV in agr(um) $p$ (edes) XXX] $]^{5}$. Thus, in relation to the fragment of information, we can conclude that, in approximate terms, the area of the building ${ }^{6}$ would have $41.8 \mathrm{~m}^{2}$, which leads to the standardization of the Roman building, since we would have two squares together forming a rectangle. We do not have the dimensions of the height of the building, since we do not have information about the floor plan. As a comparison, we find in Isola Sacra buildings with square plans whose facade and depth have 10 feet, or, in the case of upper buildings, whose facade and depth have 40 feet, as well as rectangular plans that follow the standards 10x12, 18x38 and 20x43 (Carrol, 2006: 99100). So, if we think about the respective measures, the building of Segunda Bolana, as we suppose, should be a construction with an imposing area, indicating, in this way, the wealth of the family.

\footnotetext{
${ }^{4}$ In the early death of children, for example, we find representations of togaed young people in entombment of individuals at nine months old. The family celebration idealizes the child, because, in a symbolic sense, the toga touches the presence of magistracies and their correlations with the social prestige, allusive to the condition of the deceased, had he lived until the maturity. (Cf. Huskinson, 2007: 332)

5 Transcribed by Sartori, 1990: 38. Translated by Omena, 2017. See also: Petronius. Satyricon, 6.71 .

6 The official conversion indicates that 1 foot equals $0.3048 \mathrm{~m}$; therefore, 15 feet equals $15 \times 0.3048 \mathrm{~m}=4.572$ and 30 feet, twice that, equals $9.144 \mathrm{~m}$. Then, for the surface, we simply multiply the two dimensions: $9.144 \times 4.572$, resulting in 41.8 square meters.
} 
We understand that burial areas, with the presence of fragments of funerary monuments reused (I BC - III AD), have been discovered in the current areas of Milan, such as Piazza Cavour, Via Croce Rossa, Via Fontana, Via Monte di Pietà, Via della Spiga, Area del Policlinico, Via Quadronno, Via Orti, Via della Commenda, Giardini Publici, Area di Sant'Ambrogio, Università Catolica, Parco Sempione, Area di Sant'Eustorgio and Area di San Vittore al Carpo (Donatella Caporusso et al., 2012: 126-129). In the map below, we have the indication of the numbers from one to fifteen that inform the localized areas where mortuary vestiges were found. As can be seen, we highlighted the number four, the site where was found the stela in question in the period of the sixteenth century.

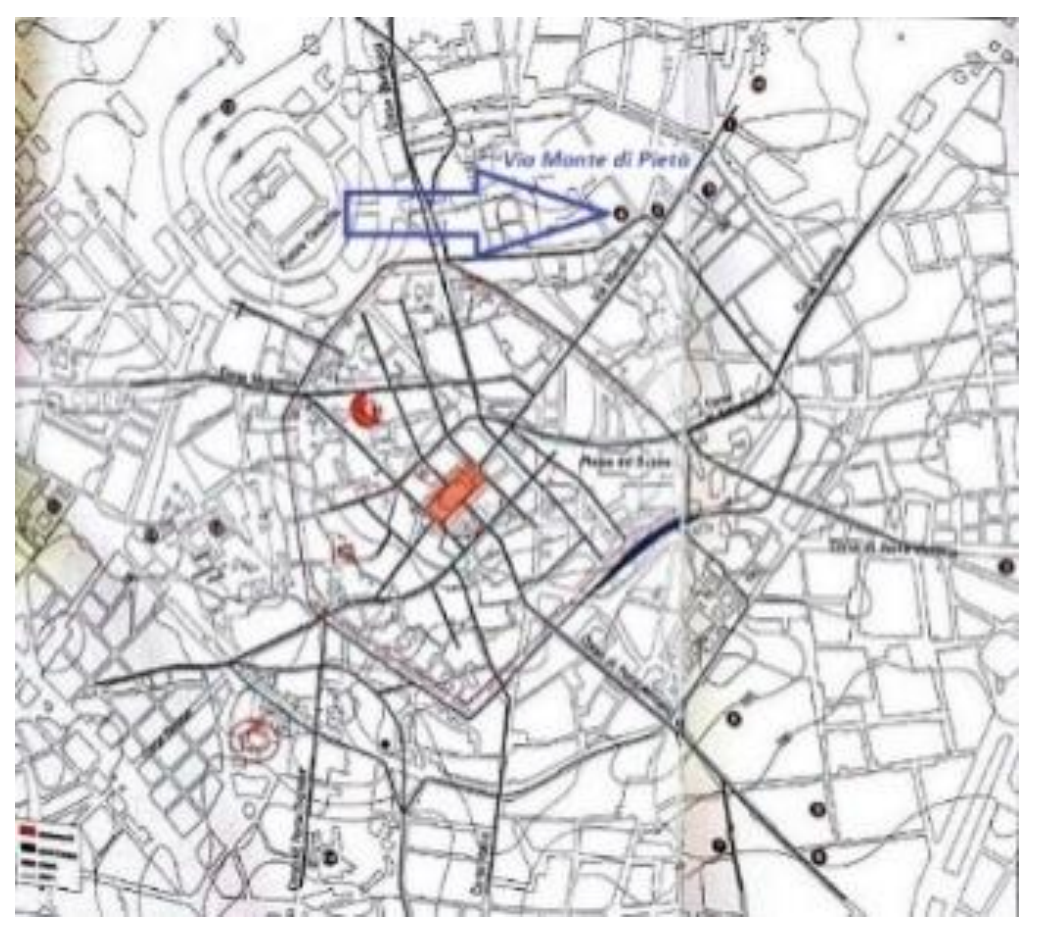

Fig. I. Current map of Milan. Here we have the places where the mortuary fragments are located (Donatella Caporusso et al., 2012: 128-129).

Faced with the possible location of the building site of the mortuary building of Bolana, the very measure of the stela - it's made of marble in a rectangular form, 2,19 cm long, $77 \mathrm{~cm}$ wide, and $65 \mathrm{~cm}$ thick - should impose its presence on the composition of the mortuary building. In addition, it is necessary to emphasize, the sumptuousness becomes remarkable by its writing. As can be seen in the drawing below (Fig. II), the tomb inscription was written in capitalis style, a script considered elegant and visible, which was often found in public and funerary monuments, and in some manuscripts, as Bischoff (1986: 55) verified in 
Virgil or in the Epistulae Morales by Seneca. Below, we see the drawing of the stele:

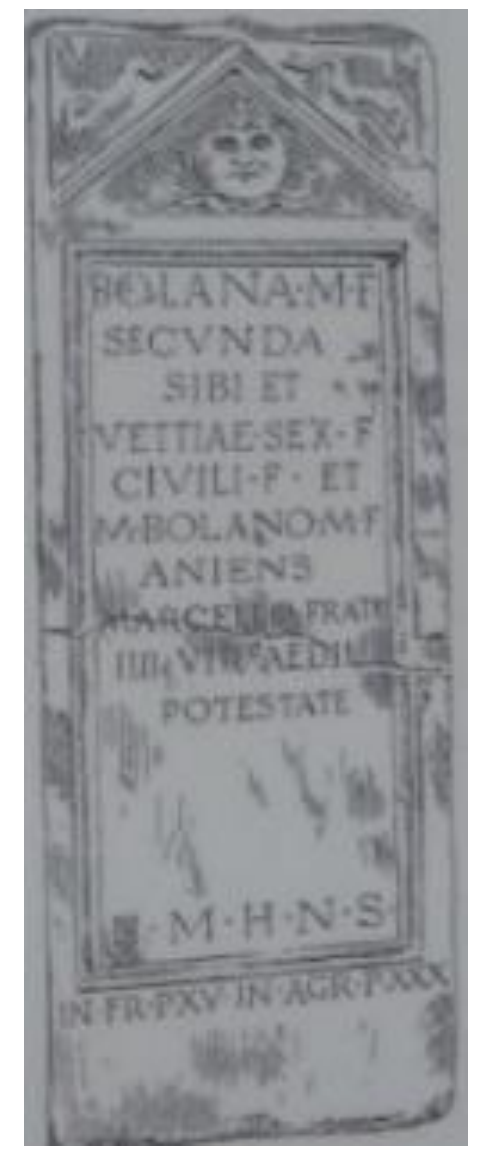

Fig. II. Drawing of the stela of Segunda Bolana (Sartori, 1994: 38).

The stone being smooth, the sculptor or scriptor titulorum produced horizontal lines with chalk, charcoal or paint to mark the top and bottom of each line of the letter. The scriptor then carved the text and, in visual terms, the message became not only more readable but also more remarkable, since the text appeared in straight lines without deformation. The words could be engraved in larger or smaller sizes, depending on what one wanted to emphasize or, in more functional terms, decrease with respect to the size of the stone for inscription. In relation to Segunda Bolana, we suppose that she emphasized her gens to the detriment of the precious information that she commissioned the memorial to herself and her relatives. As we can realize, the formula $V(i v a) f(e c i t)$ [alive she made] is on the upper part of the stela, above the representations of the dolphins. Below, we have the stela of Segunda Bolana; featuring, the image of the dolphin and the head of Medusa are evident: 

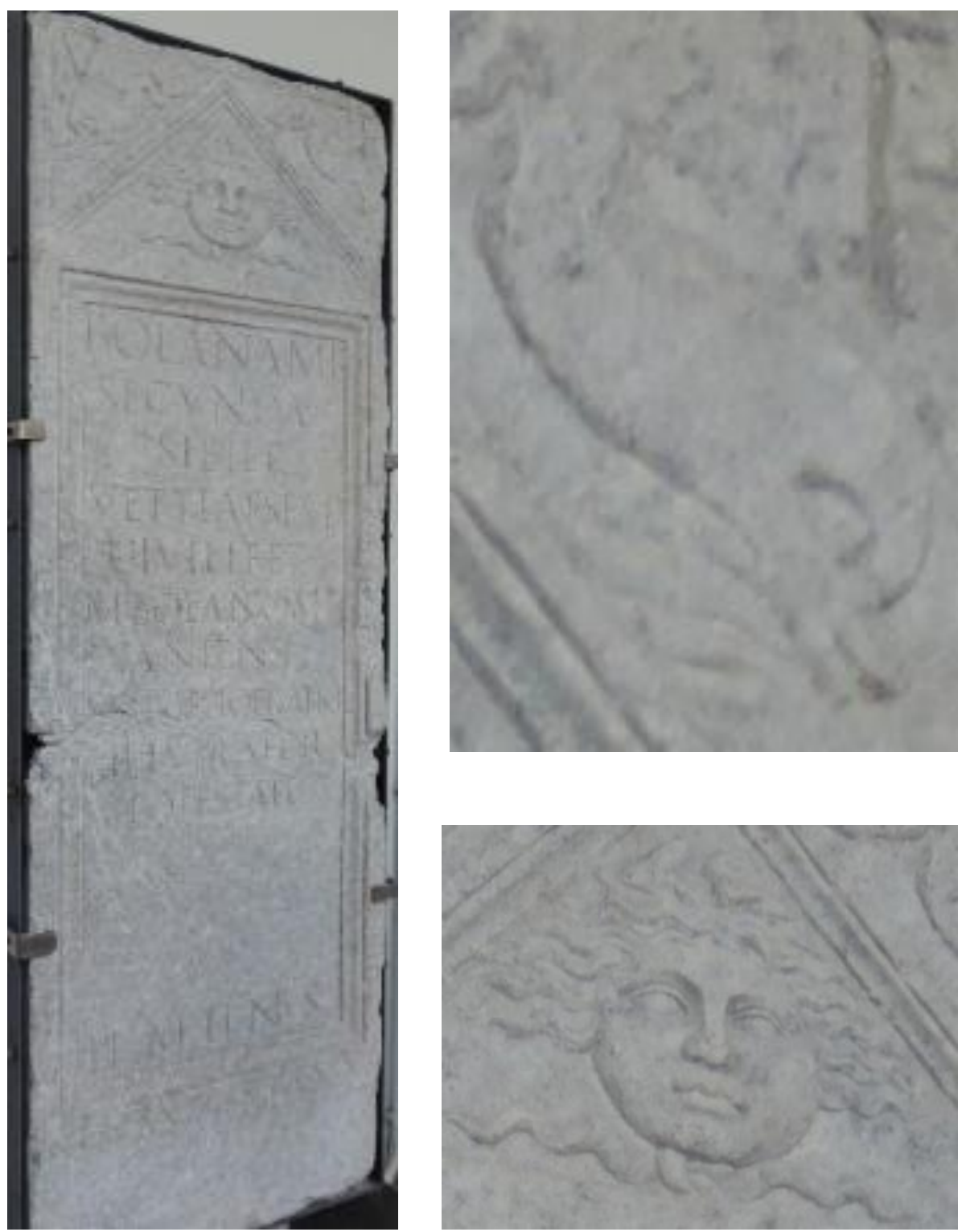

Fig. III. Stela of Bolana Segunda. N. Inv. A. 09 6600. Civico Museo Archeologico di Milano. Image credit: Omena. July 2014. Date: I-II AD

Fig. IV. Detail of the dolphin. Civico Museo Archeologico di Milano. Image credit: Omena. July 2014.

Fig. V. Detail of Medusa with intertwined serpents. Civico Museo Archeologico di Milano. Image credit: Omena. July 2014.

In addition to the glamorous presence of the marble of Musso, a town on the bank of the lake of Como, ${ }^{7}$ northern Italy, and of the writing

7 The current town of Musso stretches from the bank of lake of Como to the villages on the hillsides of Mount Bregagno. According to what is observed in the mortuary vestiges, the region possessed white marble quarries that were, as we know, exploited by the Romans. In addition to the use of this precious material in the funerary space, the Cathedral of Como and the columns of San Lorenzo in Milan had in their 
immortalizing her family, we also have decorative elements that were linked to religious practices, namely: the dolphins and Medusa. As for the dolphins (Figures III and IV), they were considered sacred animals, their intelligence and aerodynamic beauty appear in textual and iconographic evidences, determining in general the marine environment. (Hawtree, 2014: 07)

The dolphins were stylized and schematized in smaller sizes, just as we observed in the stela of Segunda Bolana; they would belong, therefore, according to our argument, to the funerary space, considering that they alluded to the symbolism of the passage to future life. That is, as well as Statius puts in the Thebaid (9.242-7), which describes dolphins leading shoals of fish to the depths, the majestic animal would also guide the dead to the manes. (Cf. Jacqueline, 2005; Macknonn, 2014)

Following, we find the representation of Medusa. Her face is rounded, and under her face we have two intertwined serpents (Figures III and V). According to our analysis, the presence of Medusa in a funerary context is common, since it has an apotropaic character. She is the guardian of the tomb. (Cf. Gillet; Mahéo, 2000: 111-112; Auclair, 2009: 94; Clo, 2013: 5355). Using John Sheid's words (2003: 140), one could say that death itself was a brutal, relentless and unavoidable kidnapping; therefore, the head of Medusa, known to cause fear and panic, since she petrified who saw her, could preserve the tomb. The hypothesis is confirmed by the reading of the Digesta, "monument is that which exists in function of the preservation of memory" [monumentum est quod memoriae servandae gratia existat] (Digesta, 11.7.2.6). So, when the monument was preserved, the memory of the dead was kept there, and of their relatives. This can also be explained by the constant violations, for looters could steal goods from the grave or, as Petronius mentions satirically, transform it into a latrine. In this sense, the character Trimalchio states: "I will then put one of my freedmen in the grave, so that the people will not go crap on my monument" [praeponam enim unum ex libertis sepulcro meo custodiae causa, ne in monumentum meum populus cacatum currat] (Petronius, Satyricon, 6.71. See also: Cooley, 2012; Remessal, 2016). ${ }^{8}$

\footnotetext{
composition the marble of Musso. Available at: http://www.comoanditslake.com/musso.htm Accessed on: August 05, 2017.

8 For this excerpt, we used Cláudio Aquati's translation (2008); however, the alteration from tomb to monument suggested in the passage is the responsibility of the authors. We believe that the Petronian text uses the noun monumentum as a synonym for memory and not, as the translator suggests, for tomb. In our understanding, the word monumentum refers to memory. Monumentum also means tomb, grave, sepulchre
} 
It is note that in this action against possible violations, the strategy of memory preservation. The epitaph fits into this strategy. We know that these inscriptions included material supports linked to burial rituals, such as the ritual of depositing remains in urns, amphoras, sarcophagi and, in our case, the ritual of messages written on stelae and funeral altars (Cf. Charles, 1983). In tomb inscriptions, we come across with precious information about feeling of loss, social relations of gender, family relations, biographical details, idealizations about the feminine and the childhood, terms of use of the grave, testament of the deceased, magistracies, crafts, among other information. (Cf. Huskinson, 2011; Newby, 2011; Birk, 2011; Riess, 2012; Omena; Carvalho, 2014; Remessal, 2016, among others) The inscriptions present at the Civico Museo Archeologico di Milano reveal characters such as, for example, Luci Veraci Terentiani, named on a funerary altar, measuring $89 \mathrm{~cm}$ in length, $34 \mathrm{~cm}$ in width and $26 \mathrm{~cm}$ in thickness. The altar has a pediment with the epigraphic formula D M (dis minibus), the greeting Have Gregori (Goodbye Gregory) and the inscription itself, framed in rectangular structures on its sides, thus composing the altar scene, with the presence of patera. There is one inscription on it (Fig. VI and VII).

As can be seen, the wife Aurelia Primiane and the brother of the deceased, Castricius Cassianus, commissioned an altar in honor of Luci Veraci Terentiani. To do so, they used epigraphic formulas, such as the lifetime of the deceased, the presence of the manes and expressions using synthetic absolute superlatives (characteristics enhancers), as in very dear husband - carissimus - or simply with adjectives that strengthen the positive particularities of the deceased, a fact noted in meritorious brother bene merens (Cf. Cooley, 2012: 128-129). At first glance, we do not observe any peculiarity if we compare this epitaph to other epigraphic testimonies; however, we identify an interesting detail: although it does not present elegiac verses and expressions of pain, as in the inscription of Lucius Trebius Divus, translated by Omena and Funari (2015), it reveals

(Ulpiano, Digesta, 47.12.3). In this sense, if we turn to the first part of his argument, sepulcrum means grave, tomb; while at the second moment of his pondering the word monumentum induces memory, since he intended to prevent possible offenses after his death by assigning a freedman the task of protecting his funeral building. This one could not become a latrine. Here we have a central question: the sepulcher where his remains would be deposited, as observed in the law ["Sepulcher is the place where the body or bones of man are deposited" - "Sepulcrum est ubi corpus ossave hominis condita sunt" (Digesta, 11.7.2.5)], should not suffer any violation, not even the funerary building, his monument of memory. Therefore, we suppose that sepulcrum and monumentum cannot be understood in this passage only as linguistic resources to avoid repetition, that way using synonymous words. 
to the passersby an affectionate greeting: Have Gregori, Goodbye Gregory ${ }^{9}$. It seems to us that the privileged position of the salutation indicates an intentional selection, making Gregory and his family visible and memorable (Sartori, 1994: 96). The numem of his patronus, placed below the reverence, becomes a mere formality, since the expected would be the direct mention of his former dominus (Smith, 2006: 15-16; Carrol, 2011: 129). ${ }^{10}$ Even though it is a stereotyped construction or, as Hodder (2012: 146; Cf. Omena; Funari, 2015) asks, transformed by death, often what people were not in life, the epitaph throws light on its most affectionate dimensions. It seems to us pertinent to infer that the greeting produces a more personal meaning to memory, especially to the fact that the brothers Castricius Cassianus and Luci Veraci Terentiani belonged to different domini (Cf. Sartori, 1994: 96). However, even in such circumstances, death would have united them in the end.

From the above, we can usually define that the commemoration of the dead in epigraphy leads us to reflect on the representations of families, since that the lives within families were linked to a system of representations that normalized the social roles (Laurence, 2012: 06), as the expressions of affection. In contrast to Luci Veraci Terentiani's epitaph, which is linked to the affective dimensions of the symbolism of death, we have, in Segunda Bolana's epitaph, the display of her gens. We quote in extenso:

V(iva) $f($ ecit) Bolana M(arci) $f($ ilia)Secundasibi et Vettiae Sex(ti) $f(i l i a e)$ Civili $\mathrm{f}($ iliae) et $\mathrm{M}(\mathrm{arco})$ Bolano $\mathrm{M}(\mathrm{arci}) \mathrm{f}(\mathrm{ilio})$ Aniens(i tribu) Marcello fratriIVvir(o) aedil(icia) potestate. $\mathrm{H}(\mathrm{oc}) \mathrm{m}$ (onumentum) $\mathrm{h}$ (eredem) $\mathrm{n}$ (on) $\mathrm{s}$ (equetur). In fr(onte) p(edes) XV in agr(um) p(edes) XXX. (Sartori's transcription, 1994: 38)

\footnotetext{
9 Have or ave is an expression of goodbye to the dead (e.g., Frater, ave. Goodbye, my brother), as well as good morning greeting, greeting someone. (Saraiva, 1993: 133; Oxford Dictionary, 1968: 210).

10 If we observe the material remains in Isola Sacra, we will see possible integration, including, we would say, a little more affective [e.g. epitaph of Lucius Trebius Divus (Omena; Funari, 2015)], among freedmen and their respective patroni. In some circumstances, the freedmen would be considered members of their families, who would bear the name of the patronus, thus revering the same numen. As Carrol reminds us (2011: 129), freedmen begin to build tombs for their patroni, and hence, year after year, perpetuate their memories in funeral ceremonies; however, social relations did not represent a one-way street; therefore, the liberti also received benefits, such as the acquisition of Roman citizenship and property, access to marriage and political negotiations, among others.
} 

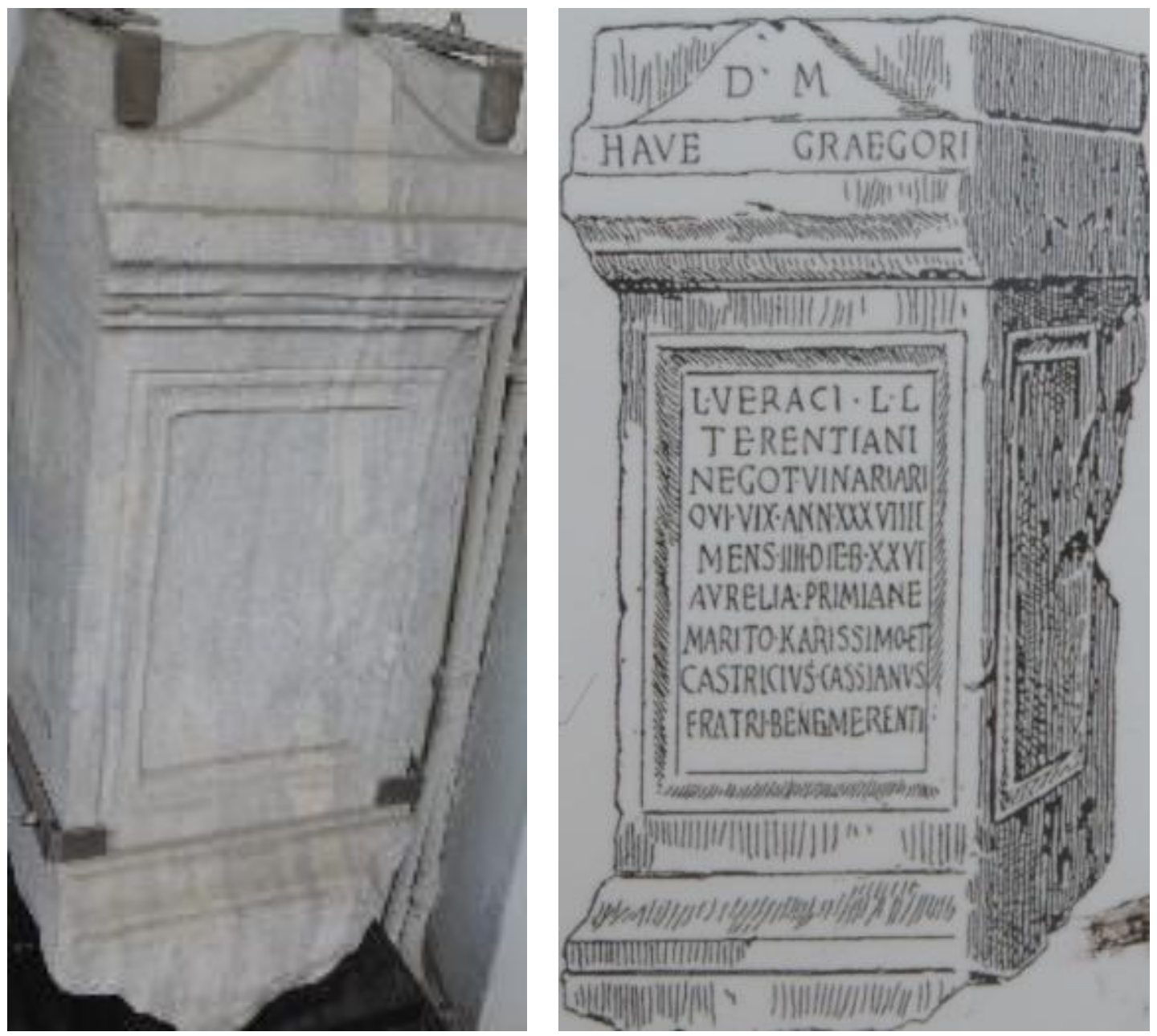

Fig. VI. Altar to Terentiani. N. Inv. A.09. 11040. Civico Museo Archeologico di Milano. Image credit: Omena. July 2014. Date: II AD.

Fig. VII. Drawing of the altar of Terentiani (Sartori, 1994: 96).

Inscription: D(is) M(anibus), Have Graegori, L(uci) Veraci L(uci) 1(iberti), Terentiani, negot(iatoris) vinariari, qui vix(it) ann(is) XXXVIIII, mens(ibus) IIII dieb(us) XXVI Aurelia Primiane et, marito karissimo et, Castricius Cassianus, fratri bene merenti. (Sartori's transcription, 1994: 96).

To the gods manes. Goodbye, Gregory. Luci Veraci Terentiani, freed from Luci, wine merchant, who lived 39 years, 4 months and 26 days. [dedicate] Aurelia Primiane, to the dearest husband, and Castricius Cassianus, meritorious brother. (Translated by Luciane Munhoz of Omena).

To the gods manes. In life, Segunda Bolana, daughter of Marcus, made [this monument] for herself and Vetia Civila, daughter of Sextus, (his) daughter and Marcus Bolano Marcello, son of Marcus, enrolled in the tribe Anieno, his brother, quadrumvirs with aedile powers. This grave is 
not transferable to heirs. 15 feet on the facade and 30 feet deep. (Translated by Luciane Munhoz de Omena)

In the case of aristocratic families, we know that they congregated a group of persons subject to the potestas of a male member; in this sense, the gens comprised all the legitimate descendants of a common male ancestor. (See: Smith, 1986: 15) In this case, Segunda Bolana, even dedicating the monument to her daughter Vetia Civila, daughter of Sextus, praises in particular her belonging to the gens Bolana. ${ }^{11}$ We know that the woman did not inherit her husband's name and was consequently not subject to his legal authority. In addition, after the death of the father, the adult daughter could receive "goods in their own right, buy or sell, inherit or make testament and free slaves." (Beard, 2016: 339) That is to say, in this case, Segunda Bolana should have considerable resources inherited from her father, and even if we do not have this information, we can infer it, since she, Bolana, commissions the graceful funerary stela to her gens. Even though she had the obligation to appoint a tutor, the inscription allows us to argue about her acting, which immortalizes the gens Bolana. It presents that in the first line of the epitaph, giving prominence to the information. Thus, the praise of the family centers on her brother, Marcus Bolanus Marcellus. He was inscribed in the tribe of Aniensis, place of voting, becoming, in this way, evident his condition of Roman citizen. ${ }^{12}$ Here we have the ennoblement of Marcellus, remembering that in this period, from the first to the second century $\mathrm{AD}$, being a Roman citizen symbolized having a high social status, a situation changed only in $212 \mathrm{AD}$, when we have the extension of citizenship to all inhabitants of the empire, thus diminishing the

\footnotetext{
${ }^{11}$ In relation to the gens Bolana, we have information of its presence in Rome. Being an aristocratic gens, it probably extended its possessions beyond Latium, reaching the Mediolanum region. In the work Vetus Latium Profanum, dated around 1742, Josepho Rocco Vulpio informs the readers about the steps of ancient writers, as in the description of an ancient village in Tusculum believed to have belonged to Cicero. Presented in Latin, the compilation informs that the gens Bolana would be illustrious and further adds that one of its members, Horatius Bolano, would be a man of complacent character. He also reports that the gens would have commissioned a stone monument in his honor. (Canina, 2012:16) Following is the text: "Ex hoc oppido Family \& Gens Bolana Romae illustris suit. Ex qua Horatius Bolanum laudat ut ingenii mitis, patientis atque perfacilis (...) Bolanæ Gentis est lapis apud Fabrettum: VF \BOLANA. M. F. SECVNDA \SIBI, ET. VECTIAE. FRI. F \CIVILI. ET \M. BOLANO. M. F. ANIENS \ARCELLO FRATRI IIII. VIRO \AEDIL. POTESTATE". (Josepho Rocco Vulpio, Vetus Latium Profanum, XII, 2.3)

12 We have other epitaphs with the same mention, as occurs with Quintus Petilius Secundus, who, dying around $50 \mathrm{AD}$, points in his epitaph the fact of voting in Oufentina, but residing in Mediolanum. (Cf. Carroll, 2006: 130)
} 
exclusivist character of the citizen's condition. (Cf. Guarinello, 2009, Beard, 2016)

The dedicator also adds the magistracy of quadrumvirs with aedile powers. In practice, this office should ensure the administration of the city in the areas of justice, finance, food supply, construction and maintenance of public order. In administrative terms, such activities were entrusted to magistrates and decurions, with seat in the municipal council, who assumed the first aedilis and, a posteriori, the duunviri. In Mediolanum, as noted in the epitaph, they had the titles quattuorvir aedilicia potestate or quattuorvir iure dicundo, which, for a term of one year, would allow them to administer the city, hold positions in the urban quaestura and still give them the opportunity to be invested in municipal religious functions. In addition, every five years, for census purposes, the quattuorviri assumed the function of censors, passing to the denomination quattuorviri censoria potestate or q. v. quinquenniales. Furthermore, in economic terms, they should contribute with large sums for financing of temple constructions, amphitheaters, food donations, among others, what made political alliances possible with local elites, thus enlarging the space for negotiation and social interaction (Cf. Hingley, 2010). We do not intend, at this moment, to deepen discussions about imperial administration or to reduce them to the devices of power, since, as Mary Beard (2016: 548) elaborates,

There was also a great movement of peoples and goods through the empire, which intensified their cultural diversity, while adding enormous profits to some and making others victim.

Certainly, to produce critical reflections on the Roman dominion is to consider the process of integration, mobility, sumptuousness and profitable commercial activities; it is also to conjecture about conflicts marked mainly by actions of disobedience, refusal to pay taxes, passive resistances and popular contestations against the local elites and against the Romans. (Beard, 2016: 557) However, we know that the administrative policy was a contribution to the promotion of local families. It did not represent the only way, but, as we suppose, it symbolized the conquest of potestas. In other epitaphs, having as reference the same social context of Mediolanum, they mentioned the presence of positions, such as scriba publicus (kind of secretary), curator aerarii (finance administrator) or even pontifex, responsible for religious assistance to magistrates in charge of traditional cults. In these circumstances, Segunda Bolana, not having another heir, since she informs to the passers-by that: "this grave is not transferable to an heir" [H(oc) m(onumentum) h(eredem) 
n(on) s(equetur)] (Sartori's transcription, 1994: 38. Translation by Omena), makes Marcus Bolanus Secundus a protagonist, since the exercise of quadrumvirs with aedile powers represented, as we have already emphasized, a source of power. Underlying a conflictive and competitive society, the sepulchral inscription immortalizes Segunda Bolana and her relatives, weaving a complex web between memory and power.

\section{Final considerations}

In reaffirming family interests, on behalf of power, Segunda Bolana immortalizes her relatives, ennobling especially her brother Marcus Bolanus Secundus, because, as we presume, the unity and stability of her gens were projected in the magistracy, making its social prestige evident. In a society composed of such political-cultural diversities, the death of a family member encompassed a complex of social practices that were expressed in varying forms of social, political, and religious communication; then, death manifested conflicts, hierarchies and more particular and emotional dimensions of the memory of the dead in the Roman Mediterranean.

\section{Acknowledgement:}

We are grateful to Pedro Paulo Funari, Ana Teresa Marques Gonçalves, José Maria Teixeira and Luciano Succi for the possibility of the exchange of ideas. The reflections developed throughout the text are the responsibility of the authors alone.

\section{Bibliographic references}

\section{Textual tradition}

Cuerpo del Derecho Civil Romano. A doble texto, traducido al castellano del latino, por D. Ildefonso L. García Del Corral. Primera Parte, INSTITUTA DIGESTA. TOMO I. Barcelona: Jaime Molina Editor, 1889.

PETRÔNIO. Satíricon. Trad. Cláudio Aquati. São Paulo: Cosac Naify, 2008. 
STATIUS. Thebaid. Translation by J. H. Mozley, M.A. Cambridge: Harvard University Press, 1928. 2 v. (Loeb Classical Library).

VULPIO, Josepho Rocco. Vetus Latium Profanum (Tomos Nonus). Romae: Bernabo \& Lazzarinus, $\mathrm{s} \backslash \mathrm{d}$.

\section{Epigraphic document}

SARTORI, Antônio. Guida alla sezione epigrafica delle raccolte archeologiche di Milano. Milano, 1994.

\section{Catalogue}

CAPORUSSO, Donatella et al. Immagini di mediolanum. Archeologia e storiadi Milano das $V$ secolo a.C. al $V$ secolo d.C. Milano: Comunedi Milano, 2007.

\section{Online resources}

http://www.comoanditslake.com/musso.htm. Acesso: 05 de agosto de 2017.

\section{Reference works:}

OXFORD DICTIONARIES. Oxford Latin Dictionary. London: Oxford at the Clarendon Press, 1968.

Saraiva, F. R. DOS Santos. Novíssimo dicionário latino-português. Etimológico, prosódico, histórico, geográfico, mitológico, biográfico, etc. Rio de Janeiro: Garnier, 1993.

\section{Bibliography}

AUCLAIR, Valérie. L'oeil médusé. Communications, 85, pp. 79-101, 2009.

BEARD, Mary. SPQR. Uma história da Roma antiga. Trad. Pedro Carvalho e Guerra \& Rita Carvalho e Guerra. Lisboa: Bertrand, 2016. 
BIRK, Stine. Man or woman. Cross-gendering and individuality on third century Roman sarcophagi. In: ELSNER, Jás; HUSKINSON, Janet (Ed.). Life, death and representation. Some new work on Roman sarcophagi. New York \Berlin: Walter de Gruyter Gmbh \& Co. KG, 2011, p. 229-260.

BISCHOFF, Bernhard. Latin paleography Antiquity and the Middle Ages. New York: Cambridge University Press, 1986.

CANINA, Luigi. Descrizione dell'antico Tusculo. Roma: Dell'associazione Culturale Liber Liber, 2012. (Eletrônico: http://www.liberliber.it/).

CARVALHO, M. M.; FUNARI, P. P. A.; CARLAN, C.U.; SILVA, E. C. M. (Orgs.). História Militar no Mundo Antigo. São Paulo: Annablume, Fapesp, Unicamp, 2012. (3 volumes).

CARVALHO, M. M.; JOSÉ, N. F. (Orgs.). Diversidades epistemológicas: A teoria aplicada à pesquisa histórica. 01. ed. Curitiba: Prismas, 2017.

CARVALHO, M. M.; FUNARI, P. P. A.; CARLAN, C. U.; PAPA, Helena Amália (Orgs.). Religiões e Religiosidades na Antiguidade Tardia. 1. ed. Curitiba: Editora Prismas, 2017.

CARROLL, Maureen. Spirits of the Dead. Roman Funerary Commemoration in Western. Oxford: Oxford University Press, 2006.

CHARLES, Pietri. Inscriptions funéraires latines. Reallexikon für Antike und Christentum, XII, Suttgart, p. 1407-1468, 1983.

COOLEY, Alison E. The Cambridge Manual of Latin Epigraphy. New York: Cambridge, 2012.

ECKARDT, Hella; WILLIAMS, Howard. Objects without a past? The use of Roman objects in early Anglo-Saxon graves. In: WILLIANS, Howard. Archaeologies of remembrance. New York: Ka \PP, 2003, pp. 141-170.

CLO, Magdeleine. La panoplie de Persée: fonctions de l'objet-attribut. Gaia: Revue Interdisciplinaire sur la Grèce Archaïque, n. 16, pp. 43-58, 2013.

GILLET, Pierre Emmanuel; MAHÉO, Noël. Sarcophages en plomb galloromains découverts à Amiens et dans ses environs (Somme). Revue Archéologique de Picardie, n³-4, pp. 77-118, 2000.

GUARINELLO, Norberto Luiz. Arqueologia e cultura material: um pequeno ensaio. In: BRUNO, Maria Cristina Oliveira et al. Arqueologia do 
Mediterrâneo antigo. Estudos em homenagem a Haiganuch Sarian. Campo Grande, MS: Life Editora, 2011, pp. 161-168.

Império romano e identidade grega. In: FUNARI, Pedro P. A.; SILVA, Maria Aparecida de Oliveira. Politica e identidades no mundo antigo. São Paulo: Annablume, 2009, pp. 147-162.

HAWTREE, Laura. Animals in Epic. In: CAMPBELL, Gordon Lindsay. Animals in Classical thought and life. Oxford: Oxford University Press, 2014.

HINGLEY, Richard. O imperialismo romano. Novas perspectivas a partir da Bretanha. São Paulo: Annablume, 2010.

HODDER, Ian. The present past. An introduction to Antropology for Archaeologists. England: PEN \& SWORD BOOKS LIMITED, 2012.

HUSKINSON, Janet. Iconography: another perspective. In: RAWSON, Berly; WEAVER, Paul. The Roman in family: status, sentiment, space. Oxford: Oxford University Press, 1999, pp. 233-238.

. Roman children's sarcophagi. Their decoration and social significance. Oxford: Oxford Monographs on Classical Archaeology, 2006.

memorials. Hesperia Supplements, vol. 41, Italy, pp. 323-338, 2007.

JACQUELINE, Genet. Yeats et la mort. Études Irlandaises, $\mathrm{n}^{\circ} 30 \mathrm{n}^{\circ} 1$, pp. 3754, 2005.

KEPPIE, Lawrence. Roman Inscriptions. Baltimore: Taylor \& Francis eLibrary, 2002.

LAURENCE, Ray. Introduction: from oikos to familia. Looking forward? In: LAURENCE, Ray; STRÖMBERG, Agneta. Families in the Greco-Roman World. London and New York, 2012, p. 01-09.

LING, Roger. Mosaics. In: BORG, BARBARA. A Companion to Roman Art. Oxford: John Wiley \& Sons, Ltd, 2015, pp. 268-285.

LORENZ, Katharina. Wall Painting. In: BORG, Barbara E. The art Roman. Oxford: Wiley Blackwell, 2015, pp. 252-267. 
MACKNNON, Michael. Fauna of the Ancient Mediterranean world. In: CAMPBELL, Gordon Lindsay. Animals in Classical thought and life. Oxford: Oxford University Press, 2014.

NEWBY, Zahra. In the guise of gods and heroes: portrait heads on Roman mythological sarcophagi. In: ELSNER, Jás; HUSKINSON, Janet (Ed.). Life, death and representation. Some new work on Roman sarcophagi. New York \Berlin: Walter de Gruyter Gmbh \& Co. KG, 2011 (p. 189-228).

OMENA, L.; FUNARI, P. P. A. (Orgs.). Práticas Funerárias no Mediterrâneo Romano. 1. ed. Jundiaí, SP: Paco, 2016.

OMENA, L. M.; FUNARI, P. P. A. (Orgs.). Experiências sociais da morte: diálogos interdisciplinares. 1. ed. Jundiaí, SP: Paco Editoria, 2017.

OMENA, Luciane Munhoz; FUNARI, Pedro P. A. O ridículo de um funeral: a simbologia da morte na sátira Apocolocyntosis de Sêneca. In: OMENA, Luciane Munhoz; FUNARI, Pedro P. A. As experiências sociais da morte: diálogos interdisciplinares. Jundiaí, SP: Paco Editorial, 2017, pp. 53$80(\mathrm{~d})$.

Tecendo o fio entre memória e morte à luz do tumulus de Otávio Augusto. In: OMENA, Luciane M. de; FUNARI, Pedro Paulo A. Práticas funerárias no mediterrâneo romano. Jundiaí, SP: Paco Editorial, 2016, pp. 69-104 (c).

. O fio da memória: o condutor dos mortos nos Parentalia. In: BORGES, Airan \& SOUTELO, Raquel Soutelo. Escrito para a eternidade: a epigrafia e os estudos da antiguidade. Curitiba: Ed. Appris, 2017(a).

Reminiscencias de la muerte y la divulgación del dolor en la estela funeraria de Lucius Trebius Divus. Anuario del Centro de Estudios Históricos "Prof. Carlos S. A. Segreti", Córdoba (Argentina), año 14, n 14, pp. 173-181, 2014 (b).

Lamento e dor: tradução do epitáfio de Lúcio Trébio Divo (séc. III-IV d.C.). Revista Est. Fil. e Hist. da Antiguidade, Campinas, ${ }^{\circ}$ 29, jan-dez, pp. 195-206, 2015.

OMENA, Luciane Munhoz de; CARVALHO, Margarida Maria de. Morte e gênero em Sêneca: um diálogo com os vestígios da cultura material. Sociedade Brasileira de Estudos Clássicos, São Paulo, Anablume, pp. 223- 244, 2014. 
REIS, João José. A morte é uma festa. Ritos fúnebres e revolta popular no Brasil do século XIX. São Paulo: Companhia das Letras, 1991.

REMESAL, José Rodríguez. Aspectos legais do mundo funerário. In: OMENA, Luciane M. de; FUNARI, Pedro Paulo A. Práticas funerárias no mediterrâneo romano. Jundiaí, SP: Paco Editorial, 2016, pp. 25-46.

RIESS, WERNER. Rari exempli femina: Female Virtues on Roman. Funerary inscriptions. In: JAMES, Sharon L.; DILLON, Sheila (Ed.). A companion to women in the Ancient World. London: Blackwell Publishing Ltd., 2012 (p. 491-501).

SCHEID, John. Les reliefs du mausolée d'Igel dans le cadre des représentations romaines de l'au-delà. L'antiquité Classique, Tome 72, pp. 113-140, 2003.

SMITH, C. J. The Roman Clan. The gens from Ancient ideology to Modern Anthropology. Cambridge: Cambridge University Press, 2006.

WALLACE-HADRILL, A. Rome's cultural revolution. Cambridge: Cambridge University Press, 2008. 